\title{
Seismic Interpretation of presalt carbonate reservoirs of the Búzios Field, Santos Basin
} Pedro Henrique Cunha de Macedo ${ }^{1, *}$, Débora Ribeiro Barretto ${ }^{1}$, Igor de Andrade Neves ${ }^{1}$, Francisco Romério Abrantes Junior $^{1}$, Wagner Moreira Lupinacci ${ }^{1}$

\author{
${ }^{1}$ Exploratory Interpretation and Reservoir Characterization Group (GIECAR), Department of Geology and Geophysics, \\ Universidade Federal Fluminense, Niterói, RJ,Brazil
}

Copyright 2021, SBGf-Sociedade Brasileira de Geofísica

This paper was prepared for presentation during the $17^{\text {th }}$ International Congress of the Brazilian Geophysical Society held in Rio de Janeiro, Brazil,16-19August 2021.

Contents of this paper were reviewed by the Technical Committee of the $17^{\text {th }}$ International Congress of the Brazilian Geophysical Society and do not necessarily represent any position of the SBGf, its officers or members. Electronic reproduction or represent any position of the SBGf, its officers or members. Electronic reproduction or storage of any part of this paper for commercial pur
of the Brazilian Geophysical Society is prohibited.

\begin{abstract}
The Brazilian presalt carbonate reservoirs are one of the most requested places for oil and gas industry exploration due to its production capacity. Oil and gas companies are often taking place to collect information about geology and the reservoirs characteristics, to consequently improve production results. Seismic interpretation is mandatory to understand the geology, always thinking about reducing all the risks during exploration. Seismic and well data are commonly used together as a way to comprehend geological history and provide a good reservoir characterization. In this paper, we performed the seismic interpretation on presalt carbonate reservoirs of Búzios Field within the isopach maps strategy and TecVA attribute. As results we achieved better definition of faults distribution and tectonics behavior, determined the main interval thickness and the possibility of coquina banks occurrence.
\end{abstract}

\section{Introduction}

The Santos Basin represents the largest presalt exploration and production area in Brazil. It currently accounts for more than $70 \%$ of the country's oil and gas production (ANP, 2021). In this context, the Búzios Field is considered a super-giant field with an estimated volume in place of 3,058 million bbl of oil equivalent and, in January 2021, the outstanding result of $146,524 \mathrm{Bbl} / \mathrm{d}$ was achieved by the platform with the highest oil production in the country located in Búzios Field.

The carbonate sedimentation processes are extremely sensitive to climatic factors, hydrodynamics, basin tectonics and morphology. These differences might cause vertical and lateral heterogeneity effects in seismic facies (Porta, 2015). In the Santos Basin, the main reservoirs are found inner coquinas (a type of sedimentary rock composed mainly by shells and their fragments) of the Itapema Formation (Castro, 2019) and in the spherulitic, laminate, shrubs and reworked facies of the Barra Velha Formation (Gomes et al., 2020).

Castro (2019) showed that the Itapema Formation in the Búzios Field is less influenced by the presence of fines and has better permeabilities than the Barra Velha
Formation. Both formations are important presalt exploration targets and have quite different sedimentarytectonic contexts. The objective of this work is to understand the evolution of the rift and sag phases in the Búzios Field area, through the integration of well and seismic data. This article intends to collaborate for a better understanding of the paleoenvironments of the Itapema and Barra Velha formations.

We interpreted four important unconformities in the presalt zone: (i) Economic basement; (ii) Jiquiá-Buracica unconformity (separates Piçarras from Itapema Formations); (iii) Pré-Alagoas unconformity (the top of coquina deposits and acts dividing the Itapema from Lower Barra Velha Formations); and (iv) the Base of Salt.

\section{Geological Setting}

The Santos Basin is located on the southeastern Brazilian margin, bounded by the Campos Basin at the North, and the Pelotas Basin at the South. Santos Basin is one of the most extensive offshore Brazilian basins, with an area of $352,000 \mathrm{~km}^{2}$, and a current water depth of up to $3,000 \mathrm{~m}$. The main structural features are the Cabo Frio High to the Northeast and the Florianópolis Platform to the Southwest, the Santos hinge line to the west, which marks the external (western) limit of the salt (Ariri Formation), and the São Paulo plateau to the East. The Búzios Field is located at the Santos Basin (Figure 1).

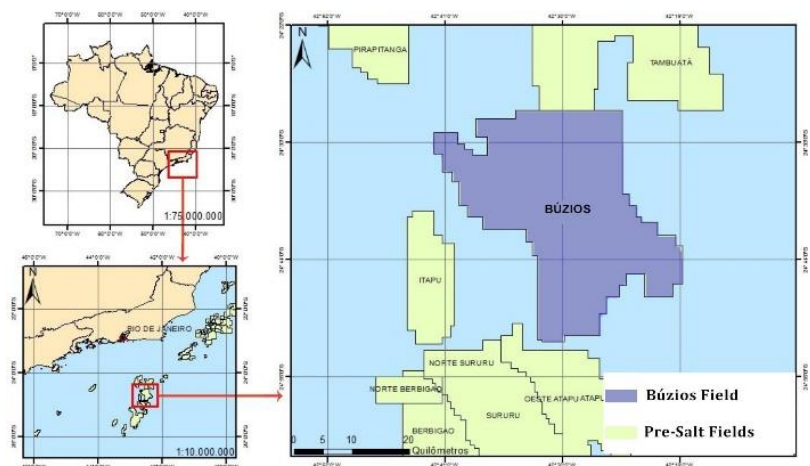

Figure 1 - Búzios Field Location (adapted from ANP, 2016).

According to Moreira et al. (2007), the geological history of the Santos Basin can be divided into three phases: Rift, Post-rift and Drift. The Rift phase presents extension efforts of separation between the South American and African plates, which started from the Lower Cretaceous.

Muniz and Bosence (2015) describe that the sequence of tectonic events that caused the fragmentation of Gondwana would have started from the stretching and thinning process of the continental crust, triggering a 
rifting process. This fragmentation consisted of a mixed process controlled by lithospheric stretching and thermal anomalies.

The crystalline basement of the Santos Basin, generated in the context of Gondwana's amalgamation, is characterized by granites and gneisses of pre-Cambrian age of the Coastal Complex and metasediments of the Ribeira Strip (Moreira et al., 2007).

During the main rifting process, around $145 \mathrm{Ma}$, the Northwest portion remained closed while a wedge was extended to the south, along the east of South America (Szatmari and Milani, 2016). According to the authors, volcanism would have been absent where the lithosphere was thick.

An important consequence during the Rift Phase was the space-forming mechanism for sedimentary accommodation in an extensional tectonic setting, and widespread normal faults generation due to mechanical subsidence process; besides causing reactivation of faults in the Precambrian basement (Mohriak, 2008). Strugale et al. (2021) point out that the different basement compositions represent another determining factor for the way the rifting process takes place. Where the basement is heterogeneous, the pre-existing fabric was reactivated whenever its orientation was favorable, producing faults as the extension direction rotates, whereas low to very low angle basement fabric were cross-cut by rift faults. Where the basement was homogeneous and more stable, only the previous formed faults remain active throughout the rifting.

Another effect observed was the contribution and influence of thermal anomalies in the region of the Santos Basin, which would have been responsible for inducing the strain softening process since the beginning of the rift, leading to the development of uplifted areas (ANP/LEBAC, 2003). The importance of understanding the different processes related to the rifting phase is the influence during the deposition of the overlying sedimentary layers.

The rift super-sequence is composed of continental siliciclastics, talc-stevensite ooids with interbedded lacustrine coquinas and organic-rich shales of the Piçarras and Itapema formations, consisting of essentially continental sediments (Szatmari and Milani, 2016).

Furthermore, during the Rift Phase, the sediments from the bottom of the Barra Velha Formation were deposited (Buckley et al., 2015). These deposits show a prominent wedge geometry, which may represent differences in the faults movement rate that consequently created space for accommodation. Thus, they state that this may represent an increase in the sedimentation rate at the top of the
Barra Velha Formation when compared to the Piçarras and Itapema formations.

The post-rift sequence, also known as the sag phase, is represented by the Upper Barra Velha Formation, which is characterized by shrubs, spherulite, laminate and reworked facies (Gomes et al., 2020) precipitated nonmarine carbonate successions (Wright \& Barnett 2015).The absence of unambiguous palaeoecologically significant fossils, together with the presence of the mineral stevensite rather than marine-derived evaporates (sulphates and chlorides), indicates an alkaline lacustrine setting with a volcanic source area (Wright \& Barnett 2015).

In short, the presalt reservoir rocks are in the Itapema and Barra Velha formations. The Itapema Formation is represented by grainstones to bivalves (coquinas), wackestones and bioclastic packstones, carbonate shales and dark shales, rich in organic matter, which sometimes also work as source rocks. The Barra Velha Formation is composed of carbonates deposited in lacustrine environment with a multiplicity of facies from boundstones and grainstones to mudstones. The Itapema Formation is limited at the bottom by the Jiquiá/Buracica unconformity $(126.4 \mathrm{Ma})$ and at the top by the Pré-Alagoas unconformity, while the Barra Velha Formation is limited at the bottom by the Pré - Alagoas unconformity and at the top by the Base of Salt (Moreira et al. 2007).

\section{Seismic Interpretation}

The seismic data provides information about the regional context, depositional system, tectonic history and allows inferring geological features and heterogeneities, favoring better understanding of sedimentary basins.

The interpretation of seismic reflection terminations, such as onlap, downlap, toplap and erosive truncations, are the main criteria for the recognition of stratigraphic units (Figure 2). They are essential to better understand what happened, allowing to foresee the current geological behavior.

Then, the identification of seismic parameters was made to recognize information about the depositional environment, source of sediments and the geological context, in which the seismic facies were deposited.

For this study, we used a PSDM volume (post-stacked depth migration) and applied a structural smoothing filter to remove part of migration smile noises.

Data from 15 wells (Figure 3) helped in the seismic interpretation from the identification of the boundaries between the lithostratigraphic units. Previous works were also fundamental for a better understanding of the sedimentary-tectonic history of the study area. 


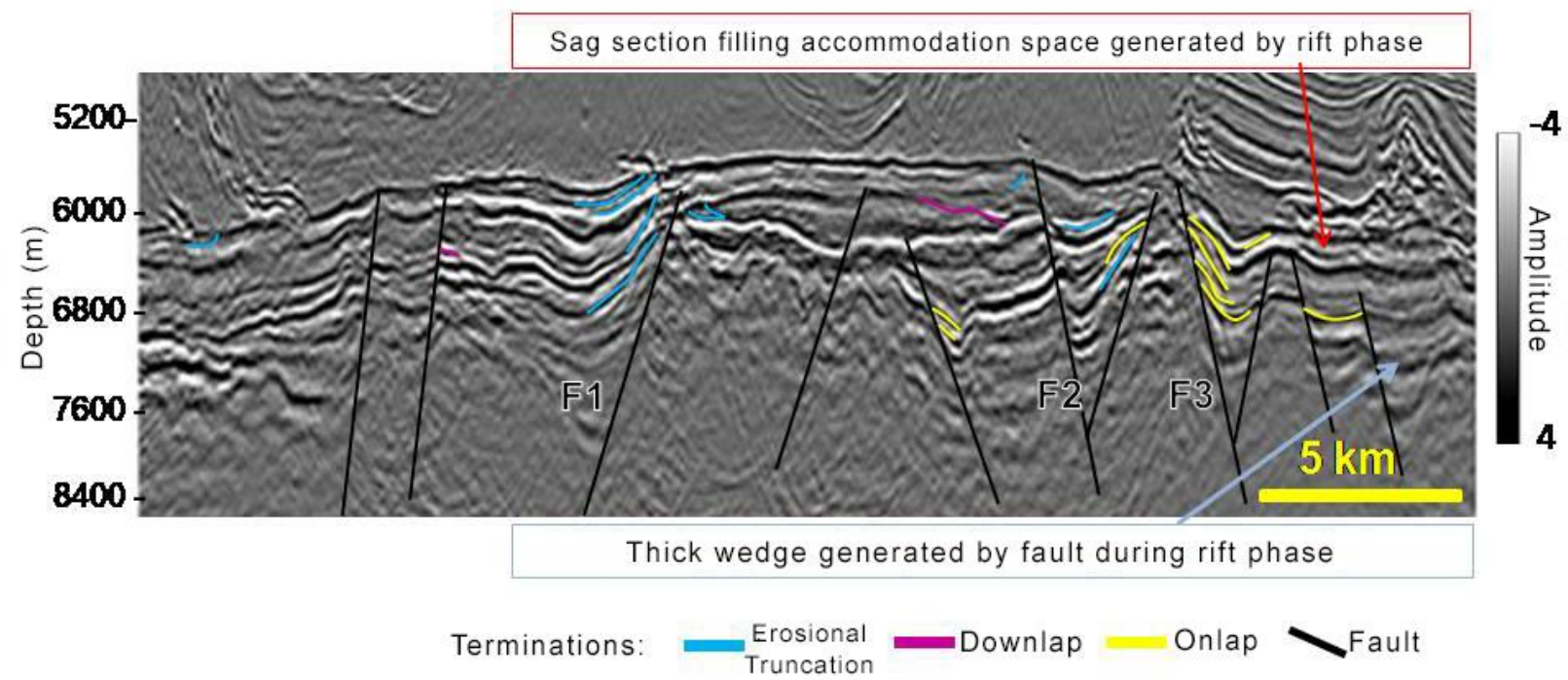

Figure 2 - Section AA'. Schematic stratigraphic sequences and the angular relationships defining the boundaries of stratigraphic units.

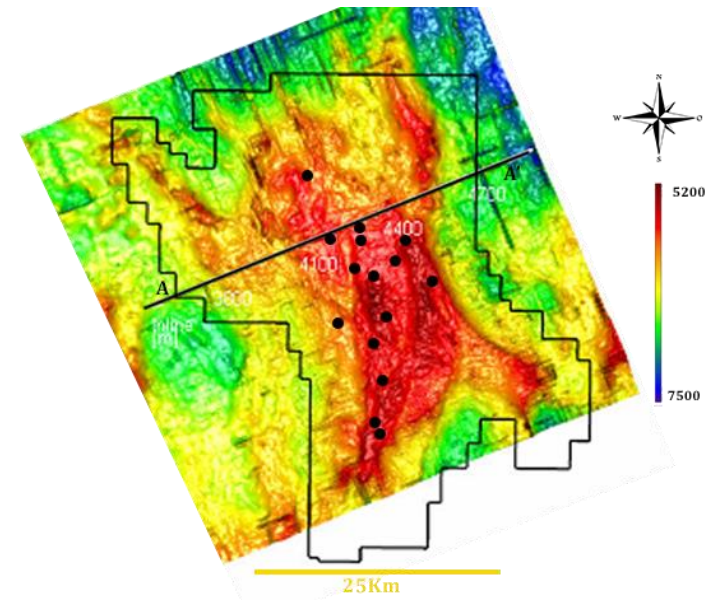

Figure 3 - Grid of the Base of Salt - Búzios Field. Wells in black dots. $A A^{\prime}$ ' is the interpreted crossline.

In carbonate rocks, due to the high heterogeneity of these rocks, the integration of well and seismic data is essential for the reservoir characterization. The steps used to develop this work are shown in Figure 4.

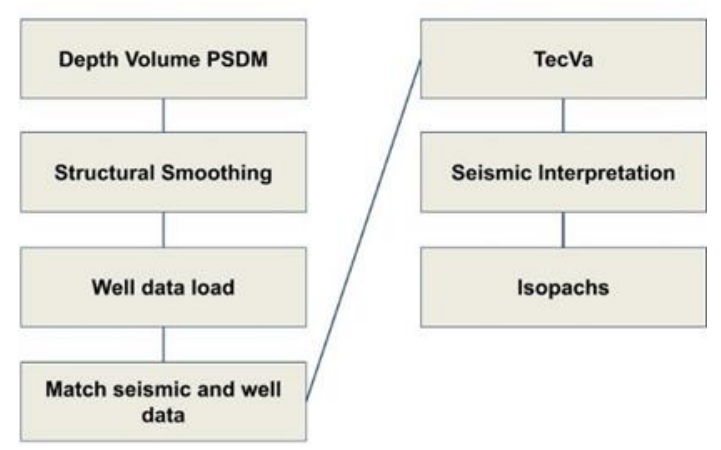

Figure 4 - Workflow used in this work.

We recognize on Figure 2 the erosional truncations (in blue) as reflectors that end on an upper surface, results of possible erosion, especially in the region at east of the F1 fault, which caused a strong slope in the strata. We also visualized the amount of onlap markings (in yellow), present mainly in the region of a build-up, to the east: the horizontal strata that end in an inclined surface, being in this case a possible build-up. This onlap configuration is very present in places with faults that were generated during the rifting process, which has influence on the formation of accommodation space and generation of wedges in the synrift interval (red and light blue arrows, Figure 2).

We interpreted the Economic Basement as a high amplitude reflector due to the high amplitude contrast of the basalts with the siliciclastic deposits of the Piçarras Fm. The TecVA attribute (Bulhões and Amorim, 2005) helped during the interpretation of the basement. This attribute was co-rendering with the seismic amplitude and allowed to improve the characterization of the seismic facies below the basement, which is characterized as chaotic of low amplitude. In addition, TecVa also highlighted the faults of the presalt section (Figure 5-b). The typical pattern of the basement is the absence of internal reflections or the presence of chaotic reflections.

We noticed that the presalt interval in the Búzios Field has horst-graben systems, characteristic of extensional basins (Figure 6). The faults are very consistent along the entire rift. These two aspects have influence on geological sedimentation and the faults might act as fluid conductors throughout the sections. In the study area, the fault orientation is N-S and can reach up to $2 \mathrm{~km}$ of reject. In the syn-rift segment, we observed medium to low amplitude reflectors, with subparallel and wavy configurations of medium continuity and low frequency, representing deposits of clastic sediments of the Piçarras Formation. The next unconformity interpreted was JiquiáBuracica, to delimitate the lower Itapema Formation. The coquinas have been interpreted as lacustrine deposits located at structural highs, deposited under shallow and high-energy conditions (Figure 6). The Itapema Formation presented progradational to chaotic seismic facies during 
seismic interpretation. Debris flow were also identified according to seismic reflection terminations added to the amplitude information, possible result of the fragmented configuration due to rifting process.
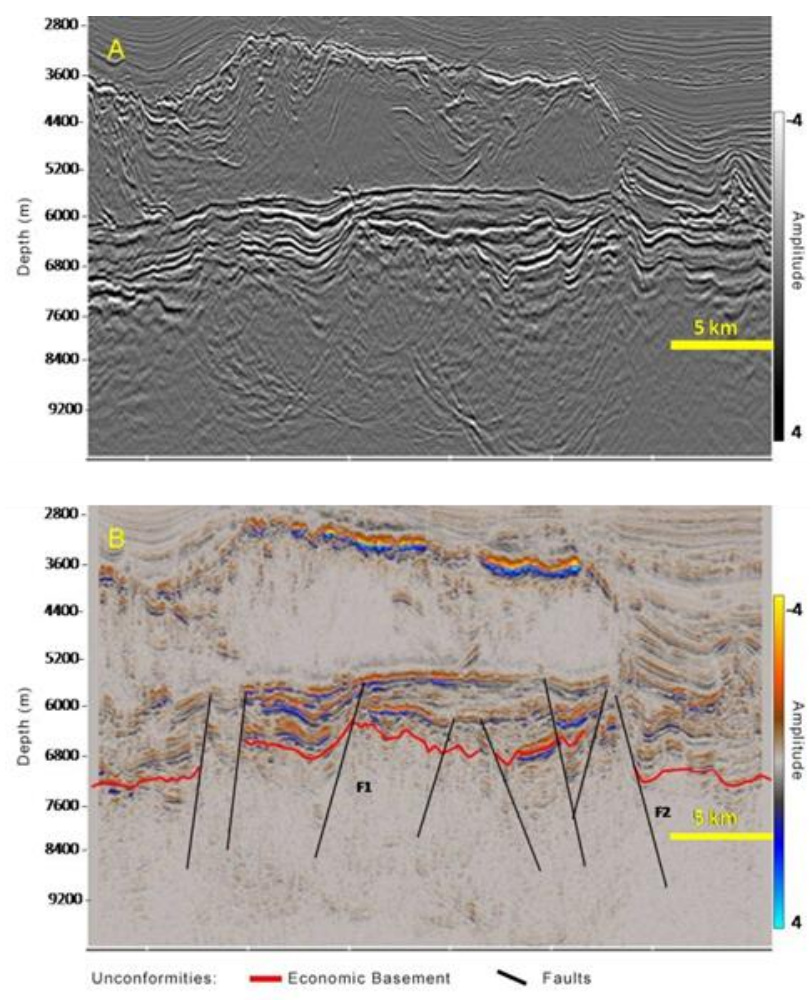

In the Pré-Alagoas unconformity interpretation, it was possible to observe higher amplitudes within planeparallel seismic facies. The Barra Velha Formation is also subdivided into upper and lower Barra Velha, where the lower one is affected by a rifting characteristic tectonic regime and is described by reworked facies, with rudstones and grainstones being the prevailing facies (Silva et al., 2014).

The upper one, beneath the salt, shows a predominance of flat arrangement in situ facies, portraying a sag phase (tectonic quiescence). Because of this aspect, the layers are displayed stable. We recognized the transition between lake bottom patterns of the upper rift phase passing upward to aggradational/progradational carbonate platform during the sag phase, indicating distal facies at the base of the sequence, which can be attributed to the fault development in the region during the Barra Velha Formation.

It is possible to visualize in the Figure 6 that the coquina bank is limited by two normal faults, F1 and F2, sectioning the coquina bank in the central part of a structural high. As can be seen between faults F2 and F3 (Figure 6), the thickness of the Barra Velha Formation was increased, which was caused by the faulting and horst and graben configuration (especially in high regions). We point out this effect as accommodation space creation.

The Sag phase is assigned as a period of tectonic quiescence. However, we can notice faults that reach the Base of Salt (Figure 6), leading to the discussion about the presence of some tectonic activity in this period.

Figure 5 - Original Seismic (A) and TecVA attribute (B). Economic basement interpreted in red.

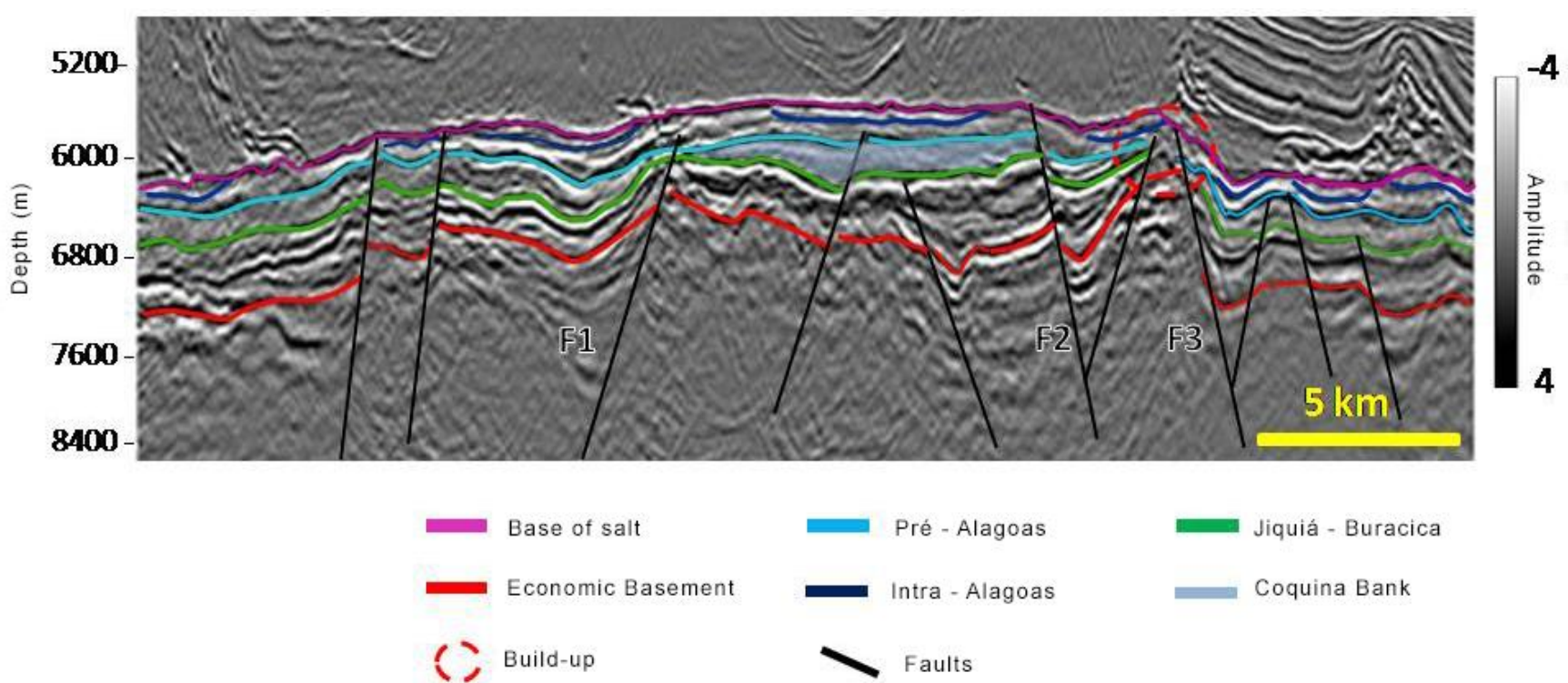

Figure 6 - Seismic section through Búzios Field, with unconformities and faults interpretation. F1, F2, F3 represent important faults. F1-F2 act compartmentalizing the coquina bank, highlighted in light blue. F1 and F3 show their extension till the base of salt. It is also possible to recognize a build-up at the East and a Horst-Graben configuration. 
We identified the following seismic patterns during interpretation:

- Carbonate build-ups probably controlled by hydrothermal activity at the edge of high structural faults and isolated at high locations.

- Facies of platform carbonate sedimentation controlled by topography and bathymetry, presenting aggradational or progradational character.

- Extensive carbonate platforms with planeparallel architecture.

- Debris flow (to the right of F3), correlated to the tectonics.

The carbonate mounds are often recognized presenting an internal low-amplitude reflectors behavior, with great possibility to be an excellent reservoir (Jesus et al. 2019; Ferreira et al. 2021). The build-ups display aggradational geometries that are onlapped and overlain by evaporates (Figure 2). Above the Barra Velha Formation, during the Neoaptian, the evaporites of the Ariri Formation were deposited. The base of the salt has a high amplitude characteristic and acts as the hydrocarbon seal at the region.

\section{Isopachs}

An isopach map provides information on a geological horizon, while combined with other geological information, enables the geologist to interpret the activity and the history of this layer and its time segment. An isopach map focuses on a special horizon and allows thickness analysis.

Based on the isopach maps (Figure 7), we analyzed the thickness of each reservoir interval, Itapema and Barra
Velha formations, and thus better understand their deposition phases over time, which is characterized as an important step for future modeling.

To the southeast, we see a thickness increase of the Barra Velha Formation (Figure 7a), with mounds improving permoporous characteristics, due to the large dip-slip faults. At this location, the creation of accommodation space was very high. The Figure $7 \mathrm{~b}$ displays a thickness increase at the central part of Itapema Formation, at the same place where was possible to observe coquina bank restricted to the highs between the main faults.

Szatmari and Milani (2016) also point out that there is an increase in the occurrence of oil reserves at the south of Santos Basin. According to the authors, the main reasons for this are the increase of generator rocks amount to the south with the widening and deepening of the rift. This increase was displayed in Figure 7.

\section{Conclusions}

(i) Evidence of faults affecting the upper rift and sag sections in the location of section $A A^{\prime}$ indicates that tectonic activity is at least locally controlling the sag phase sedimentation in some segments of the Búzios Field.

(ii) Coquinas with good permoporous properties towards the top of Itapema Formation are also associated with structural highs, influenced by faults acting as controllers.

(iii) The thickness of the Barra Velha Formation increases along the section due to geological behavior and tectonic activity. We observe that the greatest thickness of the reservoir interval is located on the structural highs of the rift phase, indicating more favorable environmental conditions for the development of carbonate facies.
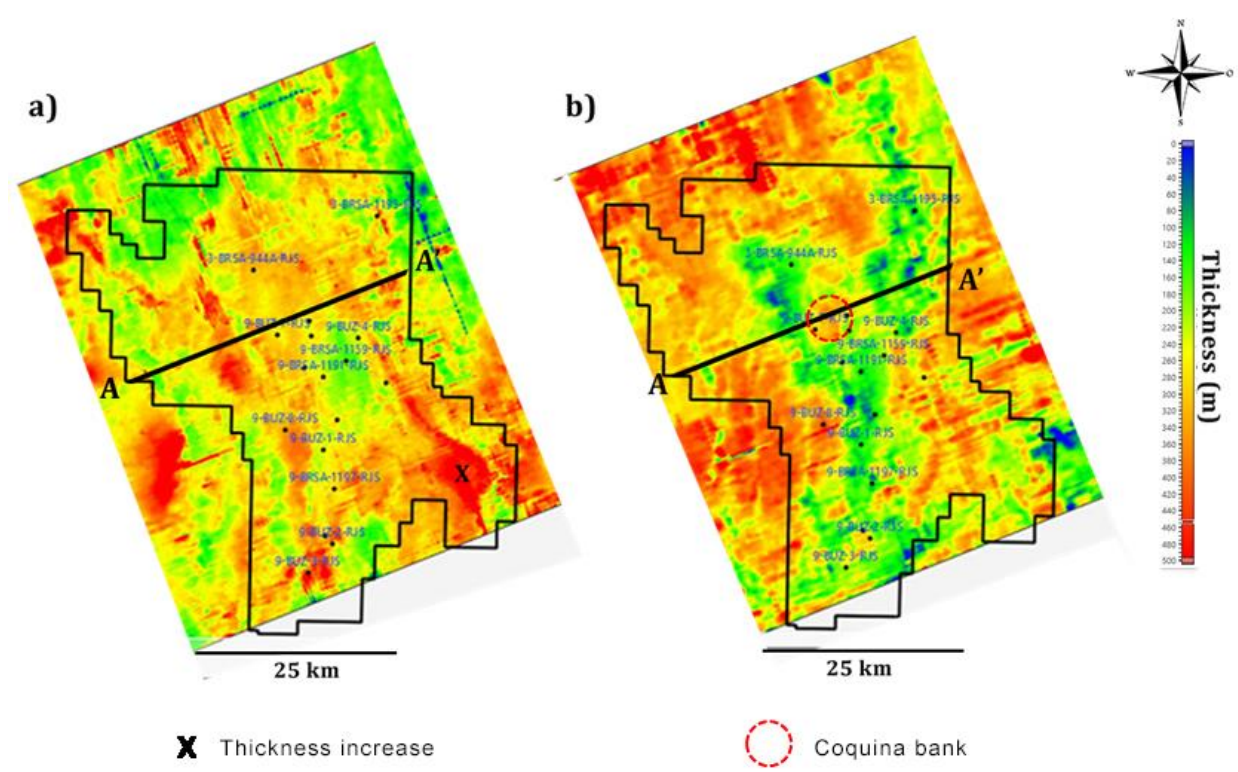

Figure 7- Isopachs showing the thicknesses of Barra Velha (a) and Itapema (b) Formations. $A A^{\prime}$ is the seismic section and $X$ point at the Barra Velha isopach map (a) displays a thickness increase, with mounds possibly improving permoporous characteristics, due to the large dip-slip* faults. The red circle on (b) displays the interpreted coquina bank in Itapema Formation. 


\section{Acknowledgments}

The authors thank ANP for providing the used data and Emerson E\&P for providing support and software license.

\section{References}

ANP. 2021. Boletim da Produção de Petróleo e Gás Natural. Superintendência de Desenvolvimento e Produção, jan. 2021.

CHINELATTO, G. F.; BELILA, A. M. P; BASSO, M.; SOUZA, J. P. P.; VIDAL, A. C. 2020. A taphofacies interpretation of shell concentrations and their relationship with petrophysics: A case study of Barremian-Aptian coquinas in the Itapema Formation, Santos Basin-Brazil. Marine and Petroleum Geology 116: 104317. .

BASILE, C.; MONTEVERDE, D. Bedding attitudes as a sequence stratigraphy proxy: A case study from borehole images, Integrated Ocean Drilling Program Leg 313, Hole M28. Geosphere, Geological Society of America, 2012, 10 (2), pp.207-220

CASTRO, T. M. 2019. Avaliação dos reservatórios carbonáticos do pré-sal no Campo de Búzios, Bacia de Santos. Dissertação (Mestrado em Dinâmica dos Oceanos e Terra) - UFF.

FERREIRA, D. J. A.; LUPINACCI, W. M.; NEVES, I. A.; ZAMBRINI, J. P. R.; FERRARI, A. L.; GAMBOA L. A. P. (2019). Unsupervised seismic facies classification applied to a presalt carbonate reservoir, Santos Basin, offshore Brazil. AAPG Bulletin, 103(4), 997-1012.

GOMES, J. P.; BUNEVICH, R. B.; TEDESCHI, L. R.; TUCKER, M. E.; WHITAKER, F. F. (2020). Facies classification and patterns of lacustrine carbonate deposition of the Barra Velha Formation, Santos Basin, Brazilian Presalt. Marine and Petroleum Geology, 104176.
MOREIRA, J. L. P.; MADEIRA, C. V.; GIL, J. A.; MACHADO, M. A. P., 2007, Bacia de Santos: Boletim de Geociênciasda Petrobras, v. 15, no. 2, p. 531-550.

MOHRIAK, W.; NEMCOK, M.; ENCISO, G.; 2008. South Atlantic divergent margin evolution: rift-border uplift and salt tectonics in the basins of SE Brazil. 294. Geological Society, London, Special Publications, pp. 365-398.

PORTA, G. D. 2015 Carbonate build-ups in lacustrine, hydrothermal and fluvial settings: comparing depositional geometry, fabric types and geochemical signature. Microbial Carbonates in Space and Time: Implications for Global Exploration and Production, 418p.

SOUZA, L.S.; SGARBI, G.N.C. 2016. Bacia de Santos: De promissora a principal bacia produtora de hidrocarbonetos do Brasil. In: Congresso Brasileiro de Geologia, 48, Porto Alegre, 2016. Resumos, Porto Alegre, Sociedade Brasileira de Geologia, p. 278-279.

STRUGALE, M.; SCHMITT, R. S.; CARTWRIGHT, J. 2021. Basement geology and its controls on the nucleation and growth of rift faults in the northern Campos Basin, offshore Brazil. Basin Res. 2021;00:1-28. https://doi.org/10.1111/bre.12540

SZATMARI, P.; MILANI, E. J. Tectonic control of the oilrich large igneous-carbonate-salt province of the South Atlantic rift: Marine and Petroleum Geology, vol. 77, p 567-596, 2016.

WALKER, R.G. 1992. Facies, facies models and modern stratigraphic concepts. In: Walker,R.G., James, N.P. (Eds.), Facies Models: Response to Sea Level Change. Geological Association of Canada, St. Johns, NF, pp. 114 